\title{
Decarbonization of the energy sector in Greece - is Greek coal mining over?
}

ABSTRACT: The following paper presents the process of decarbonization of the energy sector in Greece and points out to different methods the Greek authorities are adopting in order to reduce the emission of greenhouse gases generated by electricity production. Greece is a country which is modernizing its energy sector gradually, yet dynamically. One of the prime aims is to reduce the level of energy produced in coal-fired power plants by focusing on the renewable energy and the gas sector. In 2010 still more than half of the electrical energy was generated by lignite-fired power plants. Almost ten years later the ratio has dropped to only slightly more than $30 \%$. A significant reduction in coal consumption was possible thanks to investments in renewable energy sources, especially in the wind and solar energy sectors. Both sectors have seen a large increase in production, making renewable energy sources already accounting for over $20 \%$ of Greek electricity production. Capital-intensive investments were also made in the country's gas supply through the expansion of gas-fired power plants and gas transmission networks. As a result, natural gas remains the main source of energy for Greece next to coal. Unfortunately, a big challenge in terms of decarbonization is the need for increased imports of electricity from abroad, due to the insufficient capacity of the Greek energy sector. Therefore, the main purpose of this paper is to define a Greek model of decarbonization and

Corresponding Author: Wiktor Hebda; e-mail: wiktor.hebda@uj.edu.pl

1 Faculty of International and Political Studies, Jagiellonian University in Kraków, Poland; ORCID iD: 0000-0002-3279-7400; e-mail: wiktor.hebda@uj.edu.pl

2021. The Author(s). This is an open-access article distributed under the terms of the Creative Commons Attribution-ShareAlike International License (CC BY-SA 4.0, http://creativecommons.org/licenses/by-sa/4.0/), which permits use, distribution, and reproduction in any medium, provided that the Article is properly cited. 
to point out to its benefits and dangers. Greek strategy might serve as an example of how to successfully solve the energy issues in the countries with similar energy profile.

KEYwORDS: Greece, Greek energy sector, decarbonization, Greek coal, Renewable energy sources

\section{Introduction}

Decarbonization of the energy sector has recently become the key element in redeveloping the energy systems in European countries, especially among the European Union members. In fact, one of the major targets of the EU climate change program is to reduce the emission of greenhouse gases. The EU hopes that by 2050 all the member countries will have reached net-zero greenhouse gas emissions. Such an assumption raises some questions about the methods used to achieve this aim. As a matter of fact, energy sectors of the given EU members are highly diversified, especially when it comes to the energy mix or technological advance. The doubts mostly concern those countries which still rely quite highly on the mining sector. Coal still remains strategically important for the Greek economy but Greece can be set as an example of a country which has managed to drastically lower coal production and consumption, although the energy mix several years ago was still $70-80 \%$ based on coal.

The purpose of the paper is to define the methods and measures Greece has adopted to decarbonize its energy sector. Additionally, the article is to point out to the consequences Greek coal mining has to face.

\section{What is decarbonization of the energy sector?}

To begin with it must be explained what decarbonization of the energy sector is, how to run the process, and what its consequences are. In other words - when does decarbonization occur? How does the process occur and what are the results?

Decarbonization refers to the process of reducing emissions from burning carbon (or $\mathrm{CO}_{2}$ ) per unit of electricity generated (Grübler and Nakićenović 1996). The $\mathrm{CO}_{2}$ emission rate for the most frequently used fuels varies and amounts to: $93.46 \mathrm{~kg} / \mathrm{GJ}$ for hard coal, $107.13 \mathrm{~kg} / \mathrm{GJ}$ - lignite, $55.43 \mathrm{~kg} / \mathrm{GJ}$ - fossil gas, $73.30 \mathrm{~kg} / \mathrm{GJ}$ - crude oil and $112.00 \mathrm{~kg} / \mathrm{GJ}$ for firewood and wood waste (KOBiZE 2019). As the numbers clearly show, carbon emission (lignite in particular) is significantly higher than other fuels (e.g. fossil gas), not to mention renewable energy sources (RES). The main aim of decarbonization is, above all, to protect the natural environment and, consequently, to improve people's quality of life and health. It must also be clearly stated that 
the emission of carbon dioxide and other greenhouse gases highly contributes to the process of ongoing global warming. During the last decade this issue has been frequently raised by the EU institutions. In 2014 the representatives of the EU member countries voted through the climate and energy objectives for the year 2030, the most important of which is the one referring to the $40 \%$ reduction of greenhouse gases emission in comparison to the year 1990 (EUCO 2014). In 2018 the European Commission presented the European strategic long-term vision to reduce greenhouse gas emissions (A Clean Planet for all) (EC 2018). Its main idea is to achieve net-zero greenhouse gas emission by the second half of the twenty-first century. The issue has also been addressed to in the Paris Agreement in December 2015, according to which 195 countries agreed to take actions in order to avoid climate change and to undertake rapid reductions in emissions (UN 2015). Such an approach proves that both politicians and societies are becoming more and more aware of what might high greenhouse gas emissions and pollution lead to. These are the reasons why decarbonization of the energy sector plays such an important role in the whole program. Decarbonization is a major issue in countries where energy, to a greater or lesser extent, still relies on coal (hard or lignite) or other solid fuels. Poland and Serbia are among European countries whose energy sector is dominated by coal. Coal still remains an important source of energy in Germany, the Czech Republic and Romania, while in countries such as France, Norway or Switzerland its consumption is close to zero. The countries considered to be global superpowers also have a well-developed coal industry. For instance, China accounts for ca. a half of global production and consumption of coal and the US follows China's footsteps (respectively: 9.3\% and 8.4\%). Among the top four countries one can also find India and Russia (BP 2019). It is therefore clearly visible that decarbonization is a global problem which casts a shadow on the future economic and social development.

Decarbonization is a long-term process highly dependent on technological advance, especially when it comes to renewable energy sources. For at least several dozens of years, highly developed countries have been investing in green energy and it has already visibly outcompeted conventional sources of energy. Renewable energy sources mostly involve hydroelectric, wind and solar power plants but also geothermal, biomass and biogas power stations. However, the financial aspect is not the only factor which fosters RES development; internal factors, such a country's geographical location, are even more important in the assessment of the RES potential (each country is faced with better or worse prospects in this field). Another way to decarbonize the energy sector is to develop nuclear energy and low-emission gas technology. The energy sector of France can serve as an example of the first way. During the last two decades $70-77 \%$ of electrical energy has been produced in nuclear power plants (IAEA 2019). In the perspective of 2-3 decades, the development of the gas sector might function as a temporary solution since this technology is less harmful for the environment than coal. However, RES technologies are dynamically improving and it's likely that a technological revolution will occur in the near future, which, in turn, may offer more possibilities in terms of storage and distribution of the energy.

Unfortunately, decarbonization not only brings about positive consequences, such as clean energy, but also poses a threat for the economy and society of the country. Restructuring of the fossil fuel sector in a given country seems to be the priority in this aspect. Decarbonization means 
stepping back gradually from all the solutions which have been used to produce energy so far. In Polish case this is inevitably connected with closing coal mines, shutting down coal-fired power plants and in the long term perspective (2-3 decades) giving up on the whole coal industry. The process of transforming the energy sector into low-emission one has to be well-balanced, i.e. coal and gas-fired power plants should be shut down only after providing an alternative energy source with the capacity similar to the previous power plant. There is also a risk that leaving conventional sources of energy too hastily may result in disrupting the supply of the energy in the country (which will require buying the energy from abroad). The restructuring of the energy sector may also mean increasing the prices of electric energy, especially during the process of transformation. When it comes to the social outcomes, decarbonization is a serious challenge for mining areas, such as Upper Silesia in Poland. Restructuring might call for a complete or partial transformation of the local industry. Such a change will result in a dramatic drop in the standard of living, growing unemployment as well as the need to retrain thousands of workers and to create new places of work.

\section{The energy sector in Greece - in the direction of RES}

At the beginning of the $21^{\text {st }}$ century many European countries witnessed the beginning of the process of decarbonization. Greece also happened to be among these countries. Although its energy sector still relied heavily on lignite even several years ago, during the last decade Greece successfully managed to implement the energy strategy. What remains crucial in this matter is the National Renewable Energy Action Plan (NREAP 2009) from the year 2009 and National Energy Efficiency Action Plan (NEEAP 2014) from the year 2014. These documents point out to the priorities in the Greek energy sector - the development of renewable energy sources and increasing energy efficiency. The majority of the investments are supposed to happen in the green energy sector, however the remaining sectors are also being redeveloped, and the gas sector in particular (Hebda 2019).

Therefore, what kind of natural energy resources are available in Greece? One of the most impressive natural resource is undoubtedly lignite which can be found in different parts of the country. The newest research indicates that lignite deposits amount to 7.5 billion tons placed in four coal-mining areas. The richest one is located in Western Macedonia (1.5 billion tons) where $80 \%$ of Greek coal is mined. The next two coalfields: Drama (900 MT) and Elassona (170 MT) are also located in the north of Greece. Greeks can mine coal in Megalopolis (225 MT) in the Peloponnese (Tzeferis 2015) (Fig. 1). It is reported that so far 30\% of the coal resources have been mined and if the production remains stable, the resources will last for the next 40 years (Euracoal 2020). Crude oil and natural gas resources are reported to be rather scarce, however there are some hopes that newly discovered hydrocarbon resources next to Crete might turn out to be useful. 

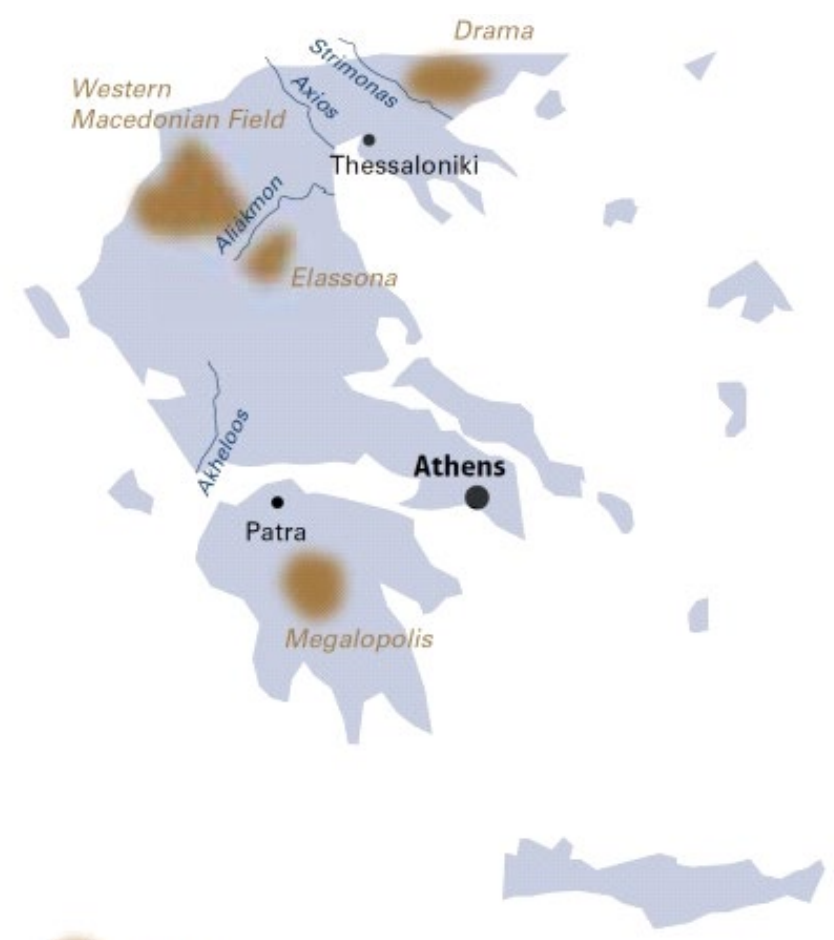

Lignite

Fig. 1. The most important lignite deposits in Greece Source: Euracoal 2020

Rys. 1. Najważniejsze pokłady węgla brunatnego w Grecji

Without any doubts, Greece's enormous potential encourages RES development. Naturally, the strongest renewable energy source is solar energy - Greece can boast of having 250 sunny days a year, which amounts to 3,000 hours annually. What is also important is the fact that Greece's solar potential is equally placed all over the country so there are no geographical limitations to the location of solar power stations (Hebda 2019). Wind energy also seems to be a viable energy source. The fact that Greece is surrounded by the sea while its territory is mostly mountainous makes this country a perfect place to generate energy from wind. The islands on the Aegean Sea, in particular the Cyclades and the northern areas of mainland Greece have the greatest chance to develop wind power stations (Chatziargyriou et al. 2016). Greece also comes first in the European ranking of geothermal potential. What is more, this kind of energy is easily accessible technologically-wise and also profitable - tectonic and volcanic activity has led to thermal energy being accumulated not very deep in the ground and also to the creation of multiple water reservoirs with low, average and high enthalpy (Hebda 2019). However, when it comes to hydroenergy, Greece's situation seems to be far less satisfactory. Its potential is not that impressive in that matter, mainly due to the fact that the country is susceptible to long-term 
droughts. It is estimated that the energy capacity amounts to ca. 6,300 GW (12 TWh annually), $45 \%$ of which is currently being used (Neubarth 2018).

During the last decade the Greek system of electric energy production has undergone a complex process of restructuring. At present, there are three dominating sources of energy: fossil gas, coal and renewable energy sources. Greece uses hydro energy, to a lesser extent. In 2018 the production of electric energy amounted to $50,901 \mathrm{GWh}$ and although this indicator has been stable for a couple of years now, it is still $20 \%$ lower than in $2008(63,700 \mathrm{GWh})$. Such a result is a consequence of withdrawing from coal mining which accounted for almost $70 \%$ of the energy generated in the previous years. Despite that fact, in 2018 coal-fired power plants produced 17,221 GWh (33.9\%) of the energy which was only slightly less than gas-fired power plants which produced 17,252 GWh (33.96\%). In the meantime, renewable energy power stations (mostly wind and solar) produced $10,942 \mathrm{GWh}(21.54 \%)$ which means that their production doubled over the decade. Hydroelectric power stations also play a crucial role in Greek energy sector - they generated 5,486 GWh (10.6\%) (Fig. 2). Unfortunately, the amount of electric energy produced in 2018 was not enough for Greece and hence about 6,800 GWh (11.81\%) were imported, mostly from Bulgaria and North Macedonia (GEMR 2019).

Greece still has 6 lignite-fired power plants at its disposal. Most of them are located in Western Macedonia which is a coal-mining area (the biggest one is Agios Dimitrios, near the city

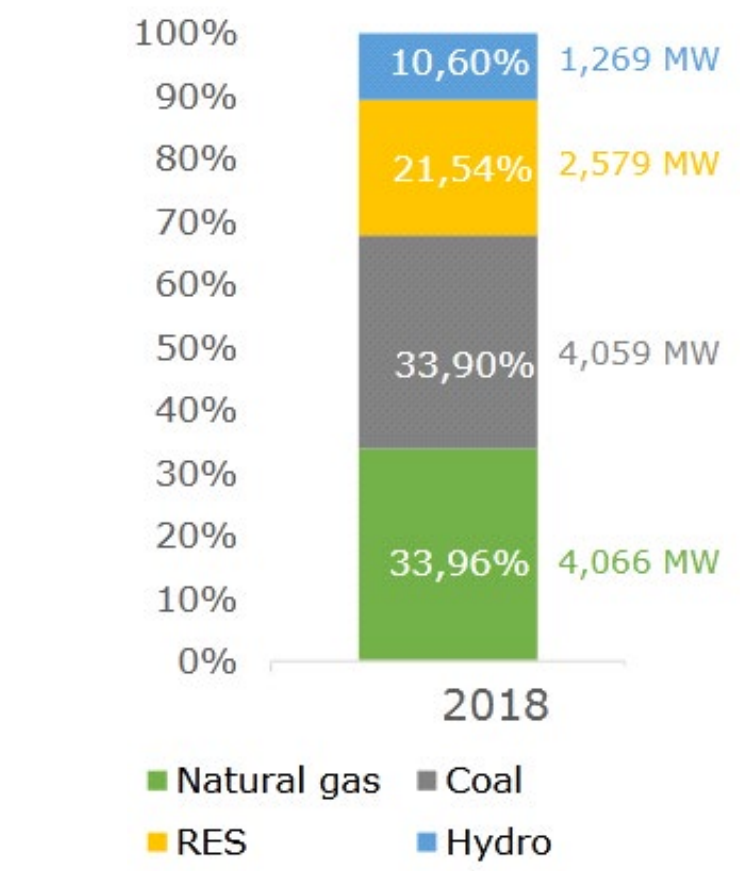

Fig. 2. Gross electricity generation by fuel [\% and MW] in Greece (2018) Source: GEMR 2019

Rys. 2. Produkcja energii elektrycznej wg źródła [\% and MW] w Grecji (2018) 
of Kozani). There is also one power plant in the Peloponnese (close to Megalopolis). Two of the power plants are supposed to be shut down in 2021. The total amount of power generated by coal-fired power plants equals 3,904 MW (in 2013 it was 5,288 MW) (GEMR 2019). The gas sector has been dynamically expanding in recent years, therefore the number of gas-fired power plants has been increasing. There are currently 13 units, with various capacities, built along the already existing gas pipeline which stretches from the border with Bulgaria and Turkey and goes through the east coast to Athens and Corinth. Taking the low $\mathrm{CO}_{2}$ emission level into consideration, most of the gas-fired power plants were built in Attica and Boeotia - regions with a high population density. Additionally, Greek gas supply sources can be quite easily diversified which makes new investments attractive. Although $80 \%$ of the gas supply comes from Russia, an increasing amount of the fuel is being imported from other countries, such as Azerbaijan or Algeria (Kastis and Kitsios 2017). The growing importance of gas-fired power plants is clearly visible through increasing energy capacity which in 2018 reached the level of 4,900 MW (GEMR 2019). Until quite recently, the Greek energy sector was also facilitated by oil-fired power plants which mostly supported energetic system of the islands, such as Crete, Euboea, Rhodes and Chios (Kastis and Kitsios 2017). In fact, the most important of these power plants were redeveloped and transformed into gas-fired ones, for instance the plants in Aliveri (Euboea), Chania (Crete) and Soroni (Rhodes).

In the last two decades the Greeks have made progress in building RES infrastructure (Fig. 3). Several wind and solar power stations were opened in various parts of the country. According to

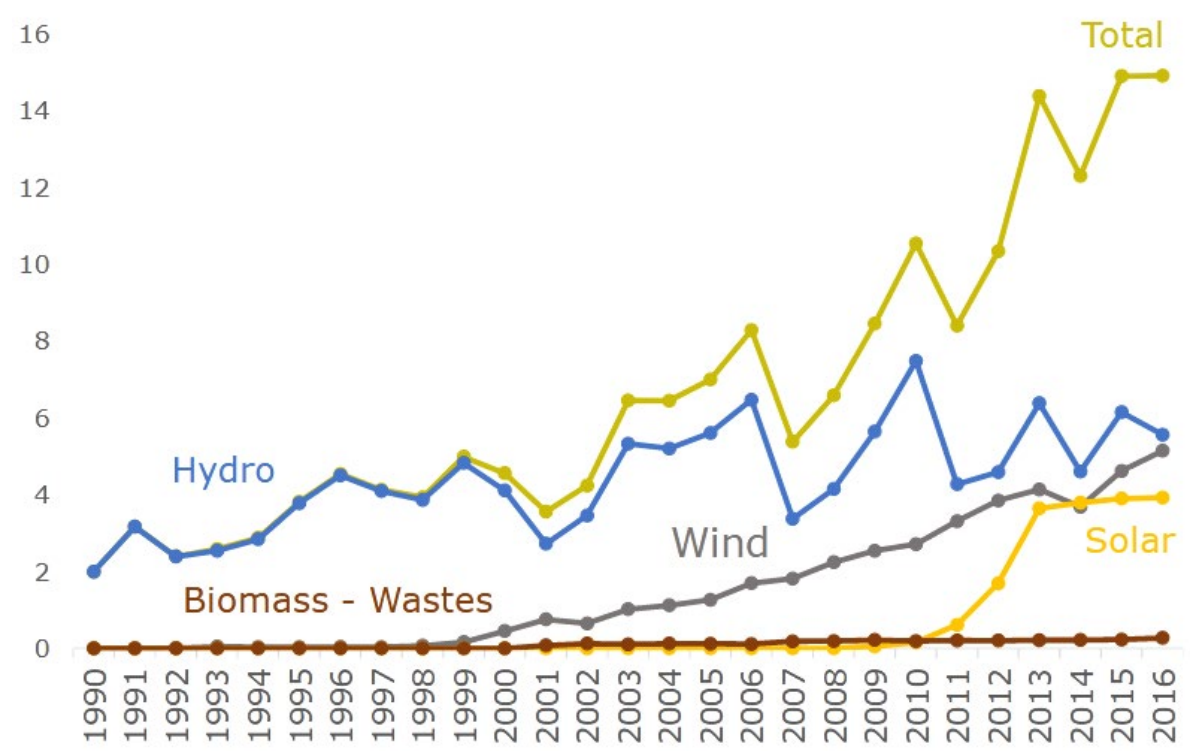

Fig. 3. Historical data of RES electricity generation in Greece [TWh] Source: GEMR 2019

Rys. 3. Dane historyczne dotyczące wytwarzania energii elektrycznej z OZE w Grecji [TWh] 
the data, in 2018 the capacity of wind power stations amounted to 2,555 MW while solar power stations $-2,491 \mathrm{MW}$ (at the beginning of the $21^{\text {st }}$ century the data was almost non-existent). Geographically wise, wind, as a source needed to produce electric energy, is most intensively used in Central Greece (907 MW), in the Peloponnese (550 MW) and in Eastern Macedonia and Thrace (375 MW). Solar power plants, though, are built in northern Greece, i.e. Central Macedonia (329 MW) as well as in Central Greece (317 MW) and in the Peloponnese (310 MW). Investments in remaining RES are rather unpopular due to the fact that small hydroelectric power stations (239 MW), biomass and biogas ( $82 \mathrm{MW}$ ) generate very scarce amount of electric energy (Kastis and Kitsios 2017).

Bearing all the above in mind, it seems clear that the future of Greek coal-mining industry is a challenge. Without any doubts, coal is a raw material which can serve as a significant source of energy for a few decades ahead (due to rich natural resources). However, according to the green energy policy, decarbonization of the energy sector is of utmost importance. Coal-fired power plants are being gradually shut down and it is likely that most of the remaining ones will be closed in the next few years. As it has already been mentioned, lignite is mostly mined in Western Macedonia (Ptolemaida - Florina coal mine, about 38 MT in 2015) and to a lesser extent in the Peloponnese (Megalopolis coal mine 8 MT in 2015). Since the production depends on the demand of local coal-fired power plants, its level has been dropping for about a decade. Only in 2010 the production amounted to almost 65 MT, in 2015, it has dropped to about 50 MT, and finally in 2018 it was a mere 38 MT (Quandl 2019). It is believed that due to the decrease in consumption, the level of mining will be dropping continuously and consequently, shutting down coal-fired power plants might force mines ultimately to close. Additionally, since transportation makes lignite less valuable and affects its quality, this only Greek raw material is not even fit for export.

\section{The energy policy of Greece - "accelerated" decarbonization}

The current energy policy of Greece has been framed in a few documents which break down the strategy into the key energy sectors. The most important document is the National Renewable Energy Action Plan (NREAP 2009) from 2009 and the National Energy Efficiency Action Plan (NEEAP 2014) from 2014. Another document - the National Energy and Climate Plan (NECP) is being currently drafted. It is a long-term plan which is supposed to standardize the Greek energy strategy. The document signed by the Greek government in 2009 - National Renewable Energy Action Plan, is still of key importance. One of the reasons why the country decided to move towards renewable energy sources was that, at the time, coal was still the main source of electric energy in Greece (78\% in 2010). Taking international obligations to protect natural environment into consideration (Directive 2009/28/EC), it became necessary to diversify the energy sector as soon as possible. Greece was obliged to implement the climate and energy 
package 20-20-20, paying special attention to renewable energy sources. It was stated that $20 \%$ of the gross energy consumption in 2020 will be produced by RES and this will be achieved by investing in cutting-edge technology and by increasing energy efficiency. It was also duly noted that in terms of RES, Greece's potential was quite significant so it was highly probable to generate energy through wind turbines or photovoltaic panels. Due to the fact that in 2008 RES accounted for only $7.8 \%$ of the gross energy consumption in Greece (most of the energy was generated from biomass), some dynamic actions had to be taken in order to reach the estimated $20 \%$ (NREAP 2009). For this reason some legal regulations were imposed. They shortened and simplified the procedures for RES development. One of such documents was issued on June 4, 2010 (L3851/2010) and it simplified the process of granting permissions, it rationalized the system of the feed-in tariffs, removed local obstacles and implemented detailed regulations on RES use in buildings (Eberle at el. 2014).

National Renewable Energy Action Plan pointed to three areas of RES development:

1. Electric energy - the increased participation of RES in the production of electric energy was supposed to be facilitated by building RES power stations, extending industrial infrastructure, shutting down old and inefficient coal-fired power plants. When it comes to the safety of energy supply and costs of RES investments Greece wad divided into two areas:

- Integrated system (continental) which was to be gradually redeveloped. One of the aims was to shut down the least efficient lignite-fired power plants and to reconstruct them so that they are suitable for biomass co-firing (to reduce $\mathrm{CO}_{2}$ emission). Another challenge was to open large RES power stations, in particular wind power stations and big hydroelectric power stations, which were supported by smaller photovoltaic, hydro, geothermal and biomass power stations. Investing in gas-fired power stations also played an important role in the energy sector.

\ Dispersed system (islands) - the aim was to shut down oil-fired power stations and promote RES. Each and every island shows a significant potential in terms of renewable sources (solar and wind energy in most cases, some of them also geothermal). A transmission grid between the islands and mainland Greece is also planned (NREAP 2009).

2. Heat engineering - the main aim of the redevelopment is to increase investments in biomass, solar and geothermal energy to provide a heating and cooling system for households and factories. Thanks to financial incentives (subventions to buy necessary equipment) as well as the simplification of administrative and legal procedures, Greek heat engineering was aiming at a decentralized, more efficient and autonomous model (NREAP 2009).

3. Transport - some steps were taken to promote fuel-efficient vehicles and to increase the consumption of biofuels in transport. In order to facilitate production and the distribution of biodiesel cars, crucial infrastructure was going to be built. This issue also concerned Greek farmers who were supposed to produce biomass and use biofuels (NREAP 2009).

The influence of RES on these three aspects varies. It is estimated that RES will play the most vital role in electric energy production (40\%), in heat engineering (20\%) and transport (10\%). Following these actions, Greece is hoping that in $2020,20 \%$ of the gross energy consumption will be generated by RES. This rating is supposed to be achieved through increasing the power 
capacity of wind power stations to $7.5 \mathrm{GW}$, photovoltaic power plants to $2.5 \mathrm{GW}$, hydroelectric power stations to $1.5 \mathrm{GW}$, biomass power plant to $250 \mathrm{MW}$ and geothermal power plants to $120 \mathrm{MW}$ (NREAP 2009).

The second document about Greek energy strategy is the National Energy Efficiency Action Plan from the year 2014. Along with the National Renewable Energy Action Plan they form the pillar of the sustainable energy policy. Its main aim is to reduce energy consumption from 20.5 Mtoe to 18.4 Mtoe in 2020 (NEEAP 2014). The target ratings are supposed to be reached through increased energy efficiency, RES investments and efficient energy consumption. In the years 2007-2012 numerous investments in modern technology generated energy savings at the level of 8.7 TWh, the majority of which (7.3 TWh) was reported in transport. However, since there hasn't been any visible change in terms of energy efficiency in the industry sector, the redevelopment of factories, involving renewable energy sources and, in this way, reducing industrial energy consumption is recommended (NEEAP 2014). There are also several other programs which take commercial recipients into consideration, for instance: "Save energy at home" or "Energy redevelopment of residential buildings" (NEEAP 2014). What is more, the Greek transmission grid has also increased its efficiency - so far annual energy loss from the transmission on the power grid has been about $6 \%$. Therefore, to minimize the loss, the transmission grid and supporting infrastructure is supposed to be rebuilt and modernized (NEEAP 2014).

For many years Greece has been struggling with insufficient capacity of electric energy which forces the country to import significant amounts of the energy. Additionally, the process of shutting down coal-fired power plants is also moving quite rapidly which makes the issue rather problematic. Also the Greek policy seems to be quite inconsistent in that matter. On the one hand, Greece promotes decarbonization but on the other, it still supports projects helping the Greek coal industry, such as the investment which started in 2015 and aims to build a coal-fired power plant in Ptolemaida 5 with the power capacity $660 \mathrm{MW}$. The investment is supposed to be ready in 2021 and is going to cost EUR 1.4 billion, which makes it one of the largest energy investments in all of Greece (Energypress 2019). For a couple of years oil-fired power plants have been gradually shut down and therefore the energy connection between Lavrion and the island of Syros is going to be built (NS Energy 2019). Such a connection will enable electric energy to be transmitted from Attica to the Cyclades and will consequently eliminate energy systems harmful to the natural environment. In the case of all the islands located in significant distance from the mainland, the planned investments will mostly focus on the redevelopment of power plants to make them use low emission fuel (fossil gas instead of crude oil). One such example is a gasfired power plant in Rhodes - it was opened in 2017 and has the capacity 115 MW (Terna 2019).

Fossil gas has been playing the key role in the energy security and the process of the decarbonization in Greece. This raw material has been gradually replacing coal in the production of electric energy, so currently gas-fired power stations are a crucial element in the Greek energy sector. What happened to be of significant help were the multiple international projects happening in the region, including Greece. When it comes to the diversification of the energy supply in Greece, the Trans-Anatolian Gas Pipeline (TANAP) played a crucial role in developing the gas sector. Additionally, opening the Trans Adriatic Pipeline (TAP) will undoubtedly strengthen 
the international position of Greece since it will become a transit country (Hebda 2014). Two gas interconnectors are also planned: Greece-Bulgaria (IGB Project) and Turkey-Greece-Italy (ITGI). The first investment is of higher priority since it will increase gas transmission from the planned terminal LNG FSRU Alexandroupoli, through Bulgaria and into the direction of Central Europe (Hebda 2015). In July 2019 the IGB Project was granted permission to construct an independent gas transmission system and to start building in Greece (31 km from Komotini to the Greek-Bulgarian border) (Caspian Barrel 2019). The ITGI project, despite its beginning in 2002, still hasn't been fully completed. Although the Turkish-Greek section (Karacabey - Komotini, $296 \mathrm{~km}$ ) has been operating since 2007, the remaining part of the gas pipeline from Greece to Italy hasn't been constructed (Komotini - Otranto, 807 km) (Hydrocarbons Technology 2019). What also works to its disadvantage is the fact that TAP project partially overlaps with the interconnector Greece-Italy. Recently, a concept of a new gas connection has emerged - project EastMed (Eastern Mediterranean Pipeline, $1900 \mathrm{~km}$ ). It is supposed to connect fossil gas deposits in the eastern part of the Mediterranean Sea with Greece, through Cyprus and Crete, and with a further possibility to transmit the gas to Italy (Fig. 4).

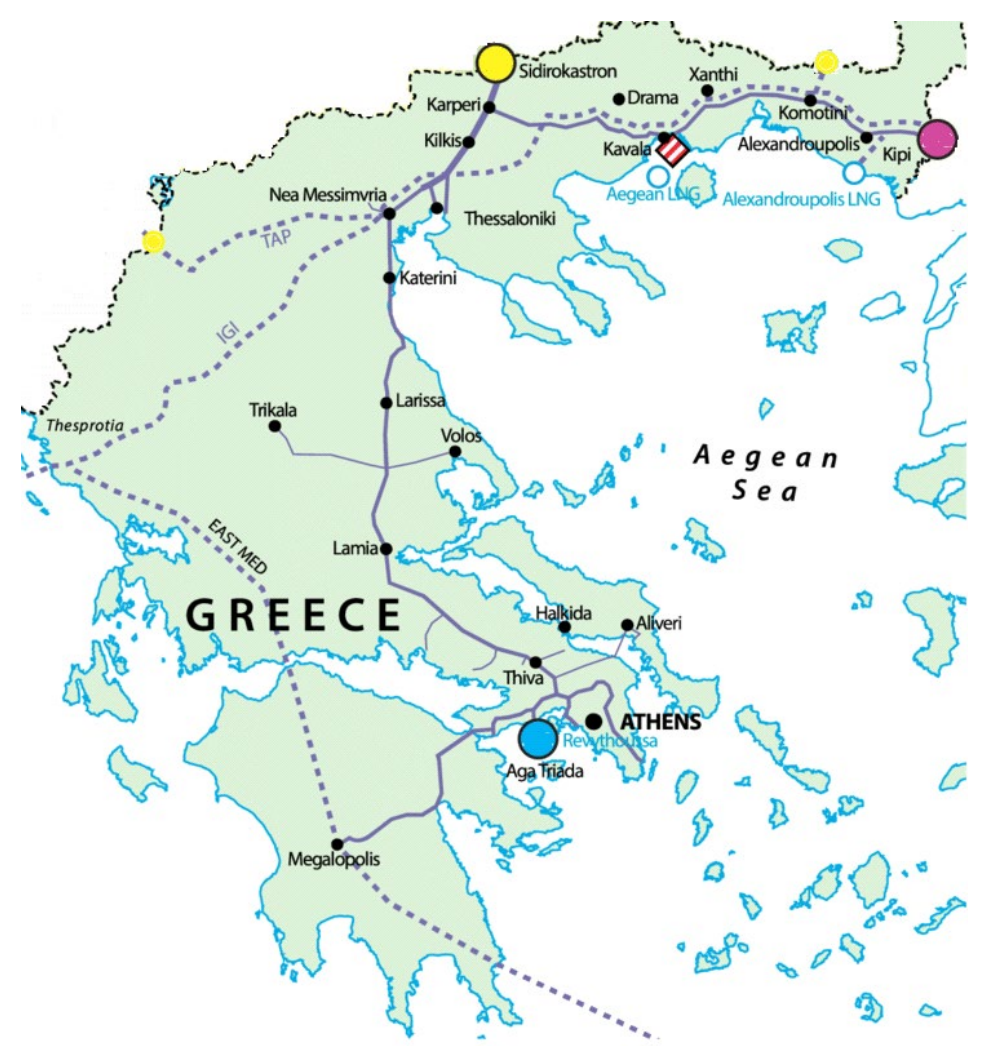

Fig. 4. Gas networks in Greece Source: Assmann 2019

Rys. 4. System przesyłowy gazu ziemnego w Grecji 
Greece is not only interested in international investments or gas interconnectors but also in the gasification of the country. As it was already mentioned, gasification in Greece is quite inconsistent. On the one hand, there are areas with a well-developed gas grid, on the other; vast territories of the country remain without any gas infrastructure. For this reason, the government is planning to expand gas network by $1600 \mathrm{~km}$ between 2017 and 2022 . The first stage is going to focus on creating a grid between 18 cities from three regions: Central Greece, Central Macedonia and Eastern Macedonia with Thrace. At further stages the grid might be expanded to Western Macedonia (GEMR 2019). Additionally, there is a plan to distribute more fossil gas to the energy center located in Megalopolis, the Peloponnese, which may lead to shutting down coal-fired power plants.

Over the last few years, Greece has witnessed a rapid growth in the use of renewable energy sources. It is a consequence not only of the EU directives but, above all, the actions taken by the Greek government, local authorities and investors, whose main aim is to increase the participation of green energy in electric energy production. On the one hand, Greece is undergoing the process of decarbonization, yet, on the other, it is also investing in the gasification of the energy sector. As a result, Greece has been struggling with insufficient power capacity. This insufficiency is supposed to be facilitated with green energy; therefore Greece is using its potential and is dynamically developing their wind and solar energy capacities. In fact, the total amount of energy generated in wind power stations in 2016 amounted to $5.1 \mathrm{TWh}$, which constituted $10.5 \%$ of the total amount of electricity produced. In the years 2010 and 2016 solar power stations increased their capacity from 0.16 TWh to 3.9 TWh $(7 \%$ of the total amount of electricity produced), therefore it is clearly visible that Greece has experienced a "solar boom".

What proves a growing interest in wind power is the fact that several energy companies are willing to invest in the wind sector, for instance Greek Terna Energy, German Anemos, French EDF, Spanish Iberdola, Luxembourg Eren - Groupe or Italian Enel Green Power, while the most important wind turbine suppliers are Danish Vestas, German Enercon and Spanish SGRE (GEMR 2019). One of the largest projects aims to build wind power stations in Crete (Crete Wind Parks) with a capacity of $950 \mathrm{MW}$ and to integrate them with the energetic network in continental Greece (through undersea Ariadne Interconnection). The project is supposed to cost EUR 2.5 billion and it will enable Greece to shut down oil-fired power plants in Crete and transform the sources of energy into green energy. As a result, the high costs of distribution and storage of oil will be reduced. One of the crucial stages of the project is connecting the electric networks between Attica and Crete - the energy surplus can be transmitted to the mainland and at the same time power shortages might be easily solved (EC 2017). New wind power plants are also going to be built on other islands and regions, for instance the Peloponnese, Central Greece, Eastern Macedonia and Thrace.

During the recent years Greece has made significant progress in using solar energy to generate electricity. Between 2010 and 2020 the government spent more than EUR 5.5 billion on the development of solar energy (Chaviaropoulos 2019). More importantly, new solar technologies are being installed in different regions of the country (both in the north and in the south) as well as on some islands. Currently photovoltaic cells cover $160 \mathrm{~km}^{2}$ of the country $(0.03 \%)$, while 
coal-fired power plants more than $1000 \mathrm{~km}^{2}$. One of the most expensive solar energy investments which is going to be ready in 2021 is the Kozani solar park ( $15 \mathrm{~km}$ from the city of Kozani in Western Macedonia). The total power of photovoltaic cells is supposed to equal $204 \mathrm{MW}$. The Kozani solar park is going to be the biggest solar power station in Greece and one of the largest in the region. What is more, this is yet another project realized by the Greek company Juwi Hellas which is a part of a German holding Juwi (Jovanović 2019). Within the next decade the capacity of solar and wind power stations is supposed to be doubled in comparison with the year 2020 (Fig. 5).

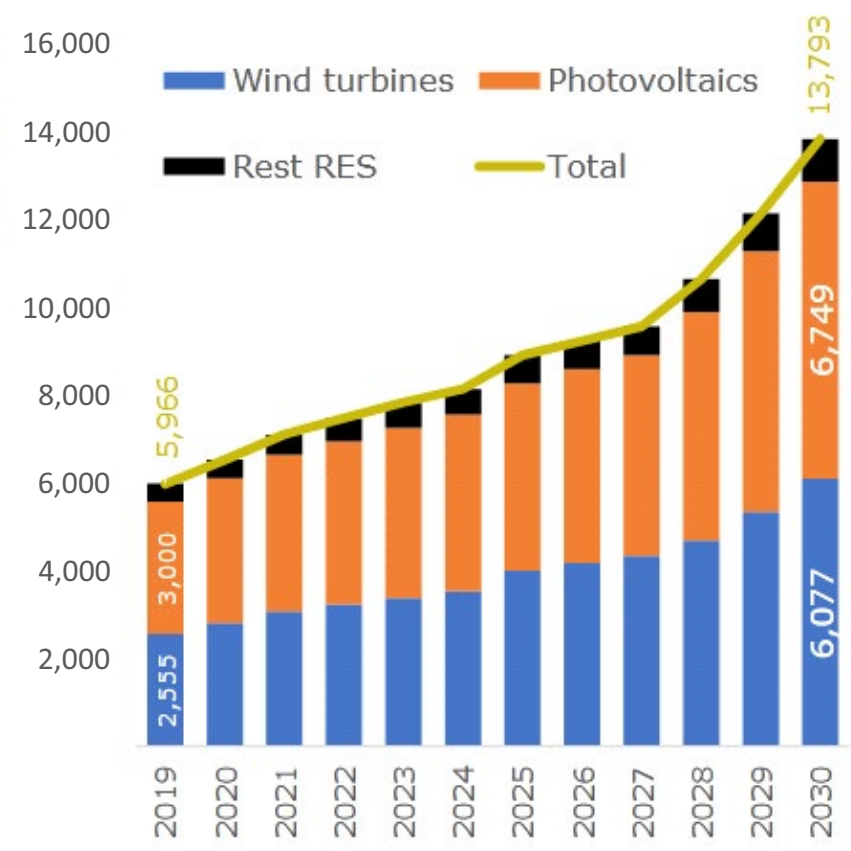

Fig. 5. Long-term forecast of RES installed capacity in Greece [MW]

Source: GEMR 2019

Rys. 5. Planowany przyrost mocy elektrycznej zainstalowanej w elektrowniach OZE w Grecji [MW]

\section{Conclusion}

Greece has been struggling with the economic crisis for over a decade. The crisis has visibly weakened the economy of the entire country. Despite that fact, the energy sector is being dynamically redeveloped - there have been numerous investments in renewable energy sources, mostly 
solar and wind power stations. Within a few years significant progress has been made which led to a gradual decrease in the production of electric energy in coal-fired power plants. A huge potential of RES in Greece along with a well-overthought energy strategy promote investments in wind turbines and photovoltaic cells. In this aspect Greece is one of the European leaders. Apart from green energy, gas engineering is also on the rise, mostly due to the fact that Greece has been exploring new possibilities of obtaining the raw material. One example is building the TAP gas pipeline and expanding the whole gas infrastructure. For several years fossil gas has been increasingly important in electrical energy production. The existing power plants have been redeveloped and equipped with gas units which contributed to the sustainability of the energy mix in Greece. The favorable geopolitical location of Greece makes it possible to diversify the key energy sources. Although over the years most of the energy has been imported from Russia, this dependency is not as problematic as in the case of Central European countries. The expanding process of gasification leads to increased import but it may also be a chance to strengthen Greek mining industry. For this reason Greece has high expectations of exploring its hydrocarbon resources located on the coastal strip stretching from north-western Greece to Crete.

The redevelopment of the energy sector and dynamic reduction of coal engineering and industry also present some threats in terms of the energetic stability of the country. After all, at the beginning of the $21^{\text {st }}$ century coal was a resource which was generating $70-80 \%$ of electric energy. Reducing the production and shutting down coal units made Greece increasingly dependent on imported electric energy. What is more, Greece can boast of having rich coal resources as well as long traditions in the coal industry. So, as a matter of fact, withdrawing from coal in the production of electrical energy means closing multiple mines, all the more so because coal is extracted mostly to meet the energetic demand of local power plants. Other challenges are retraining the workers and post-mining reclamation which will undoubtedly generate huge costs on economic and social level. Nevertheless, decarbonization is progressing and it is likely that within the decade the coal industry will be marginalized in the energy sector of Greece.

\section{References}

Assmann, D. 2019. Exact Methods for Two-Stage Rebust Optimization with Applications in Gas Networks. FAU Studies Mathematic \& Physics Band 16. Erlangen: FAU University Press, DOI: 10.25593/978-3-96147-234-5.

BP 2019. BP Statistical Review of World Energy 2019. [Online] https://www.bp.com/content/dam/bp/business-sites/en/global/corporate/pdfs/energy-economics/statistical-review/bp-stats-review-2019-full-report.pdf [Accessed: 2020-11-15].

Caspian Barrel 2019. Caspian Barrel Oil Research Center. IGB granted final license to start construction on Greek territory. [Online] http://caspianenergy.net/en/oil-and-gas/46427-igb-granted-final-licenseto-start-construction-on-greek-territory [Accessed: 2020-12-20].

Chatziargyriou et al. 2016 - Chatziargyriou, N., Margaris, I. and Dimeas, A. 2016. Renewable Energy Development in Greek Islands. Athens: Friedrich Ebert Stiftung, 32 pp. 
Chaviaropoulos, P.K. 2019. Renewable Energy Programs of Greece. [Online] http://www.academyofathens.gr/sites/default/files/Renewable $\% 20$ Energy $\% 20$ Programs $\% 20 \mathrm{of} \% 20$ Greece.pdf [Accessed: 2020-12-20].

Directive 2009/28/EC. Directive 2009/28/EC of the European Parliament and of the Council of 23 April 2009 on the promotion of the use of energy from renewable sources and amending and subsequently repealing Directives 2001/77/EC and 2003/30/EC. [Online] https://eur-lex.europa.eu/legal-content/EN/ ALL/?uri=CELEX:32009L0028 [Accessed: 2020-12-20].

Eberle at el. 2014 - Eberle, A., Donat, L., Velten E.K. and Maroulis, G. 2014. Assessment of climate change policies in the context of European Semester. Country Report: Greece. Berlin: Ecologic Institute and eclareon $\mathrm{GmbH}, 23 \mathrm{pp}$.

EC 2017. European Commission. Crete Wind Parks. Investment Project EIPP-20160074. [Online] https:// ec.europa.eu/eipp/desktop/en/projects/project-55.html [Accessed: 2020-12-20].

EC 2018. European Commission. Communication from the Commission to the European Parliament, the European Council, the Council, the European Economic and Social Committee, the Committee of the Regions and the European Investment Bank. A Clean Planet for all. A European strategic long-term vision for a prosperous, modern, competitive and climate neutral economy. [Online] https://eur-lex.europa.eu/legal-content/EN/TXT/PDF/?uri=CELEX:52018DC0773\&from=EN [Accessed: 2020-12-10].

Energypress 2019. Energypress. Greek energy news portal. Construction of Ptolemaida 5 power station set to begin. [Online] https://energypress.eu/construction-of-ptolemaida-5-power-station-set-to-commence/ [Accessed: 2020-12-18].

EUCO 2014. European Council 23/24 October 2014 - Conclusion. [Online] https://www.consilium.europa.eu/uedocs/cms_data/docs/pressdata/en/ec/145397.pdf [Accessed: 2020-12-01].

Euracoal 2020. Greece. [Online] https://euracoal.eu/info/country-profiles/greece/ [Accessed: 2020-12$-20]$.

GEMR 2019. Greek Energy Market Report 2019. Athens: Hellenic Association for Energy Economic, 144 pp.

GrÜBlER, A. and NAKIĆENOVIĆ, N. 1996. Decarbonizing the Global Energy System. Technological Forecasting and Social Change 53(1), pp. 97-110, DOI: 10.1016/0040-1625(96)00049-2.

Hebda, W. 2014. Energy Projects in the Balkans - a Chance to Strenghten Energy Security of Europe (Projekty energetyczne na Bałkanach - szansa wzmocnienia bezpieczeństwa energetycznego Europy). Przeglad Geopolityczny 9, pp. 53-70 (in Polish).

Hebda, W. 2015. Energy strategy of the Republic of Bulgaria until the year 2020 (Strategia energetyczna Republiki Butgarii do 2020 roku). Polityka Energetyczna - Energy Policy Journal 18(2), pp. 111-128 (in Polish).

HebDA, W. 2019. Politics and Energy Sector in the Selected Countries of Southeast Europe (Serbia, Croatia, Bulgaria, Greece, Romania) (Polityka oraz sector energetyczny w wybranych państwach Europy Poludniowo-Wschodniej (Serbia, Chorwacja, Bułgaria, Grecja, Rumunia)). Kraków: Księgarnia Akademicka, 210 pp., DOI: 10.12797/9788381383530 (in Polish).

Hydrocarbons Technology 2019. Hydrocarbons Technology. Interconnection Turkey Greece Italy (ITGI) Pipeline. [Online] https://www.hydrocarbons-technology.com/projects/turkeygreeceitalypip/ [Accessed: 2020-12-20].

IAEA 2019. International Atomic Energy Agency. Country Nuclear Power Profiles. France. [Online] https://www-pub.iaea.org/MTCD/Publications/PDF/cnpp2019/countryprofiles/France/France.htm [Accessed: 2020-12-11].

Jovanović, S. 2019. Balkan Green Energy News. Juwi readies to start building 204 MW Kozani solar park. [Online] https://balkangreenenergynews.com/juwi-readies-to-start-building-204-mw-kozani-solar-park/ [Accessed: 2020-12-20]. 
Kastis, S. and Kitsios, V. 2017. The energy system of Greece. A Techno-economic and Environmental Approach, University of Gävle: Faculty of Engineering and Sustainable Development, 101 pp.

KOBiZE 2019. The National Centre for Emissions Management (Krajowy Ośrodek Bilansowania i Zarzadzania Emisjami). [Online] https://www.kobize.pl/uploads/materialy/WO_i_WE_do_monitorowania-ETS-2019.pdf [Accessed: 2020-12-05] (in Polish).

NEEAP 2014. National Energy Efficiency Action Plan. Pursuant to Article 24(2) of Directive 2012/27/EU. Athens: Centre for Renewable Energy, $216 \mathrm{pp}$.

Neubarth 2018. The role of hydropower in selected South-Eastern European countries. EuroNatur Foundation and RiverWatch, $42 \mathrm{pp}$.

NREAP 2009. National Renewable Energy Action Plan in the Scope of Directive 2009/28/EC. Athens: Ministry of Environment, Energy and Climate Change, 109 pp.

NS Energy 2019. NS Energy. Nexans wins contract for Greece's Cyclades Islands power interconnection. [Online] https://www.nsenergybusiness.com/news/nexans-interconnector-cyclades-islands/ [Accessed: 2020-12-18].

Quandl 2019. Coal Production - Greece. [Online] https://www.quandl.com/data/BP/COAL_PROD_GRCCoal-Production-Greece [Accessed: 2020-12-20].

Terna 2019. Terna. Power Plant in Rhodes island. [Online] http://www.terna.gr/en/activities/energy/project-power-plant-in-rhodes-island [Accessed: 2020-12-18].

Tzeferis, P.G. 2015. Country Profile-Greece. The mining/metallurgical industry of Greece. Commodity review for years 2013-2014. Ministry of Reconstruction of Production, Environment and Energy, $88 \mathrm{pp}$.

UN 2015. United Nations, Paris Agreement. [Online] https://unfccc.int/files/essential_background/convention/application/pdf/english_paris_agreement.pdf [Accessed: 2020-11-17].

Wiktor HEBDA

\title{
Dekarbonizacja sektora energetycznego w Grecji - czy to koniec greckiego górnictwa węglowego?
}

\author{
Streszczenie
}

W artykule podjęto problematykę dekarbonizacji sektora energetycznego w Grecji, zwracając szczególną uwagę na metody, jakimi państwo greckie dąży do redukcji gazów cieplarnianych pochodzących z produkcji energii elektrycznej. Grecja jest przykładem państwa, które w dynamiczny i sukcesywny sposób modernizuje sektor energetyczny. Jednym z kluczowych założeń pozostaje obniżenie produkcji energii w elektrowniach węglowych w następstwie rozwoju odnawialnych źródeł energii oraz sektora gazowego. Problem jest istotny, gdyż jeszcze w 2010 r. ponad połowę energii elektrycznej dostarczały elektrownie węglowe operujące na węglu brunatnym. Natomiast niespełna dziesięć lat później odsetek ten obniżył się do nieco ponad 30\%. Znaczna redukcja zużycia węgla była możliwa dzięki inwestycjom w odnawialne źródła energii, zwłaszcza w sektorze energetyki wiatrowej oraz słonecznej. W obu sektorach odnotowano 
istotny wzrost, dzięki czemu odnawialne źródła energii stanowią już ponad $20 \% \mathrm{w}$ greckiej produkcji prądu elektrycznego. Poczyniono również kapitałochłonne inwestycje w gazyfikację państwa poprzez rozbudowę elektrowni gazowych oraz sieci przesyłowych gazu. W efekcie gaz ziemny obok węgla pozostaje głównym źródłem energii dla Grecji. Niestety dużym wyzwaniem w aspekcie dekarbonizacji jest potrzeba zwiększonego importu energii elektrycznej z zagranicy, co wynika z niewystarczających mocy produkcyjnych greckiej energetyki. Głównym celem artykułu jest określenie greckiego modelu dekarbonizacji oraz wskazanie na korzyści i zagrożenia z niego wynikające. Grecka strategia energetyczna może posłużyć jako przykład rozwiązania problemów energetycznych dla innych państw o zbliżonym profilu energetycznym.

SŁoWA KLUCZOWE: odnawialne źródła energii, dekarbonizacja, Grecja, grecki sektor energetyczny, grecki węgiel 
